Environmental Applied Science and Management

Dec 2015

\title{
Spreading Municipal Biosolids on Agricultural Soils - A Sustainable Waste Management Strategy or Threat to Our Streams and Lakes?
}

In major urban centres like Toronto, wastewater treatment plants not only purify and recycle water, each day they must also contend with ever-growing lagoons of domestic sewage and septic sludge. One common method of handling this so-called black water is to transform it into biosolids - organic, stabilized material, that's been treated to meet pollutant and pathogen requirements - and then ship it out of the city for land application and surface disposal.

\section{Concerns over algae growth}

On the plus side, spreading municipal biosolids over rural agricultural lands can improve soil quality and crop yields. However, while Canada has allowed such application of biosolids for almost 50 years, questions linger. Does runoff or tile leachate from fields treated with biosolids result in eutrophication of local streams and lakes? In other words, does runoff from treated fields cause nearby water sources to become over-rich in organic and mineral nutrients, thereby encouraging worrisome algae growth such as the toxic algae blooms we often see in Lake Erie?

Under the supervision of $\mathrm{Dr}$.Andrew Laursen, Aslam Hanief, a PhD candidate in Ryerson's Environmental Applied Science and Management program is one of the researchers seeking to address such concerns. Recently, Aslam was the lead author of an article in the Journal of Environmental Quality that details new findings about biosolids-amended soils and biotic response in receiving water.

\section{Simulation method}

Of the Ryerson researchers' methods, Aslam says, "In this research, we simulated a case in which heavy rainfall occurred within hours after the application and incorporation of two different biosolids (anaerobically digested and chemically stabilized) to reference soils on a weekly basis for four weeks." Surface runoff and leachate were collected after each event and added to aquatic microcosms to see if nutrients therein would contribute to eutrophication of receiving aquatic microcosms. "At the same time," says Aslam, "we compared these microcosms with reference microcosms to which inorganic nutrients were added for response to completely bioavailable forms, as is common with inorganic fertilizer application."

\section{Research highlights}

What did they find? Aslam says researchers gained a better understanding of how nutrients are removed and transformed after biosolids application. They found that nutrient concentrations were similar in the runoff from the two biosolids-amended soils -- and indeed higher as compared to the reference soil case. And while they also found that nutrients were adequately bioavailable in the water columns to stimulate algal growth, Aslam says research suggests that receiving waters could absorb a single large nutrient load associated with runoff without substantial impact. "This study, along with others conducted by the biosolids research group at Ryerson, showed no evidence of harmful physiological or behavioural effects of biosolids, or from the surface runoff and leachate from biosolids application, on flora and fauna when exposed at levels relevant to regulatory limits pertaining to biosolids application." 


\section{Support and funding}

Overall, Aslam's professional goals include producing practical and meaningful research that contributes to the betterment of society. His specific interest in waste recycling and sustainability stretches back to his undergrad thesis investigating the use of vermicomposting of various plant wastes. During his years at Ryerson, Aslam says he's been most appreciative of the "exceedingly supportive" environment he's encountered, noting in particular his lab partner Denis Matiichine, and supervisors Drs. Vadim Bostan, Andrew Laursen and Linda McCarthy.

The group's research was supported by a grant from the Ministry of Energy's Best in Science Program. 